\title{
SPOSOBY KONKUROWANIA KANCELARII PRAWNYCH Z OBSZARU WIELKOPOLSKI*
}

\section{WSTĘP}

W wyniku otwarcia dostępu do zawodów prawniczych polski rynek usług prawnych w ostatnich latach znacząco się powiększył. W porównaniu z rokiem 2005 w Polsce obecnie usługi świadczy co najmniej dwa razy więcej adwokatów i radców prawnych ${ }^{1}$ (niewiele ponad 20 tys. w 2005 i ok. 50,5 tys. w 2014 - dane szacunkowe, na podstawie raportu Naczelnej Rady Adwokackiej). Przewiduje się również, że w kolejnych latach liczba prawników będzie systematycznie wzrastać. Zmiany ilościowe powodują wzrost konkurencji w tej branży. Prawnicy są coraz częściej zmuszeni do konkurowania o klientów, a co za tym idzie - rośnie ich zainteresowanie możliwościami uzyskania i utrzymania przewagi konkurencyjnej na rynku. Do niedawna to prawnicy byli w centrum zainteresowania, a teraz zaczynają dostrzegać nadrzędną rolę nabywców usług, dlatego konsekwencją zmian stało się przede wszystkim skierowanie działań prawników na klientów. Celem artykułu jest poszerzenie wiedzy o czynnikach konkurencyjności w szczególnym rodzaju usług profesjonalnych, jakim sa usługi prawne. Jednocześnie w pracy przedstawione zostaną wyniki autorskiego badania empirycznego dotyczącego oceny czynników konkurencyjności kancelarii prawnych przeprowadzonego wśród prawników prowadzacych kancelarie prawne w Wielkopolsce. Zakres przestrzenny artykułu ma wymiar dwojaki. W części dotyczącej ogólnej charakterystyki polskiego rynku usług prawnych uwzględniono kancelarie prawne świadczące usługi w całej Polsce, natomiast w części empirycznej zbadano kancelarie prawne (adwokackie i radcowskie) z obszaru Wielkopolski.

* W artykule wykorzystano fragmenty niepublikowanej rozprawy doktorskiej autora: Wpływ jakości ustug na konkurencyjność kancelarii prawnych, napisanej pod kierunkiem prof. zw. dr. hab. Kazimierza Rogozińskiego, UE w Poznaniu, Poznań 2014.

$1 \mathrm{~W}$ artykule skoncentrowano się wyłącznie na zawodach adwokata i radcy prawnego. W rozważaniach pominięto sytuację zawodową doradców prawnych. 


\section{ISTOTA KONKURENCYJNOŚCI PRZĘDSIĘBIORSTW}

Konkurencyjność przedsiębiorstwa jest efektem oddziaływania wielu mechanizmów oraz czynników wewnętrznych (tkwiących w przedsiębiorstwie) i zewnętrznych (istniejących w otoczeniu). W tabeli 1 przedstawiono wybrane przez autora definicje konkurencyjności przedsiębiorstw.

\section{Tabela 1}

Wybrane definicje konkurencyjności przedsiębiorstw

\begin{tabular}{|l|l|}
\hline \multicolumn{1}{|c|}{ Autor } & \multicolumn{1}{|c|}{ Definicje konkurencyjności przedsiębiorstw } \\
\hline Laura Tyson & $\begin{array}{l}\text { Zdolność wytwarzania produktów, które wytrzymują test międzyna- } \\
\text { rodowej konkurencji, a konsumenci korzystają z trwale rosnącego } \\
\text { standardu życia. }\end{array}$ \\
\hline Stanisław Flejterski & $\begin{array}{l}\text { Zdolność do projektowania, produkowania i sprzedawania towarów, } \\
\text { których ceny, jakość i inne walory sa bardziej atrakcyjne od odpo- } \\
\text { wiednich cen produktów oferowanych przez konkurentów. }\end{array}$ \\
\hline $\begin{array}{l}\text { Janine Bremound, } \\
\text { Marie-Martine Salort }\end{array}$ & $\begin{array}{l}\text { Zdolność do przeciwstawiania się konkurentom, przedsiębiorstwo } \\
\text { może być konkurencyjne ze względu na cenę, jakość produktu, do- } \\
\text { bra opinię. }\end{array}$ \\
\hline Marian Gorynia & $\begin{array}{l}\text { Umiejętność osiagania i/lub utrzymywania przewagi konkurencyj- } \\
\text { nej, pojęcie tożsame ze zdolnością konkurencyjną. }\end{array}$ \\
\hline Marek J. Stankiewicz & $\begin{array}{l}\text { Zdolność do sprawnego realizowania celów na rynkowej arenie mię- } \\
\text { dzynarodowej (przestrzeń, w której zachodzi zjawisko konkurencji } \\
\text { między określonymi podmiotami). }\end{array}$ \\
\hline $\begin{array}{l}\text { Elżbieta Urbanowska- } \\
\text {-Sojkin }\end{array}$ & $\begin{array}{l}\text { Cecha przedsiębiorstwa, która ma charakter wielowymiarowy. } \\
\text { Składają się na nią konkurencyjności cząstkowe, określone w odnie- } \\
\text { sieniu do poszczególnych obszarów strategicznych. }\end{array}$ \\
\hline Edward Cyrson & $\begin{array}{l}\text { Proces, w którym uczestnicy rynku, dażąc do realizacji swych } \\
\text { interesów, próbuja przedstawić korzystniejsze od innych oferty } \\
\text { ceny, jakości lub innych cech wpływających na decyzje zawarcia } \\
\text { transakcji. }\end{array}$ \\
\hline
\end{tabular}

Źródło: opracowanie na podstawie M. Sławińska, Strategie konkurencji w handlu detalicznym w warunkach globalizacji rynku, Wyd. AE w Poznaniu, Poznań 2005, s. 43, za: J. Signetzki, Relacje partnerskie $z$ klientami a konkurencyjność przedsiębiorstw budowlanych w Polsce, Rozprawa doktorska, Uniwersytet Ekonomiczny w Poznaniu, Poznań 2011, s. 82.

Wszystkie powyżej wymienione definicje cechuje podejście do konkurencyjności jako pojęcia teoretycznego, w którym istota zachowań podmiotów gospodarczych sprowadza się do konkurowania, rywalizacji i konfrontacji. W takim ujęciu w krótkim okresie znamieniem konkurencyjności jest posiadanie przewagi nad rywalami pod jakimś względem, a w długim - atrybut konkurencyjności przysługuje organizacji, która potrafi przetrwać w konkurencyjnym otoczeniu².

${ }^{2}$ M. Gorynia, B. Jankowska, Klastry a międzynarodowa konkurencyjność i internacjonalizacja przedsiębiorstwa, Difin, Warszawa 2008. 
Celem badań konkurencyjności przedsiębiorstw jest określenie podstawowych czynników i źródeł oraz sposobów ich wpływu na rezultaty przedsiębiorstwa ${ }^{3}$. Zgodnie z poglądem Marka J. Stankiewicza konkurencyjność przedsiębiorstw powinna być rozpatrywana jako system złożony z czterech podsystemów: potencjału konkurencyjności, przewagi konkurencyjnej, instrumentów konkurowania oraz pozycji konkurencyjnej ${ }^{4}$. Potencjał konkurencyjności składa się z zasobów materialnych i niematerialnych przedsiębiorstwa, umożliwiających zdobycie trwałej przewagi konkurencyjnej nad konkurencyjnymi firmami. Z kolei przewagę konkurencyjna należy rozumieć jako efekt wykorzystania potencjału konkurencyjności, umożliwiającego przedsiębiorstwu generowanie atrakcyjnej oferty rynkowej i skutecznych instrumentów konkurowania. Instrumenty konkurowania określa się jako środki świadomie tworzone przez przedsiębiorstwo dla pozyskania nabywców. Pozycja konkurencyjna jest natomiast rozumiana jako osiagnięty przez firmę wynik konkurowania w danej branży, analizowany na tle wyników realizowanych przez konkurentów ${ }^{5}$. Powyższe elementy odzwierciedlają wiele istotnych uwarunkowań, które maja wpływ na konkurencyjność przedsiębiorstw. Istotne jest, aby czynniki te analizować w sposób kompleksowy i dostrzegać ich wzajemne powiązania oraz zależności.

\section{SPECYFIKA KONKURENCYJNOŚCI USŁUG PROFESJONALNYCH ${ }^{6}$}

Problematyka konkurencyjności w literaturze ekonomicznej opisywana i rozwijana jest przede wszystkim na podstawie działalności przedsiębiorstw produkcyjnych, a w niewielkim stopniu uwzględnia specyfikę usługową ${ }^{7}$. W artykule podjęta została próba wykazania odmienności koncepcji pojmowania konkurencyjności przez organizacje usługowe w odróżnieniu od przedsiębiorstw produkcyjnych. Podobnie jak dostawcy przedmiotów materialnych także usługodawcy działają na rynku w obecności konkurentów, którzy również dążą do utrzymywania dotychczasowych oraz pozyskiwania nowych

${ }^{3}$ Z. Pierścionek, Strategie konkurencji i rozwoju przedsiębiorstwa, PWN, Warszawa 2003, s. 165 .

${ }^{4}$ M. J. Stankiewicz, Konkurencyjność przedsiębiorstwa. Budowanie konkurencyjności przedsiębiorstwa w warunkach globalizacji, Towarzystwo Naukowe Organizacji i Kierownictwa „Dom Organizatora”, Toruń 2002, s. 184-185.

5 Ibidem.

${ }^{6}$ Usługi profesjonalne są terminem wprowadzonym na bazie analizy marketingowej, natomiast w nomenklaturze statystycznej są one nazywane usługami biznesowymi. O charakterystyce tych usług więcej w: K. Rogoziński, Zarzadzanie profesjonalna praktyka medyczna, Wolters Kluwer Polska, Warszawa 2009, s. 32-33 oraz M. Chłodnicki, Usługi profesjonalne przez jakość do lojalności klientów, Wyd. AE w Poznaniu, Poznań 2004.

7 Podobnie jak dostawcy przedmiotów materialnych, również usługodawcy działają na rynku w obecności konkurentów, którzy również dążą do utrzymywania dotychczasowych oraz pozyskiwania nowych klientów. Nie wszystkim usługodawcom udaje się ten cel osiąnąć w pożądanym przez nich stopniu, co wynikać może z różnego poziomu ich konkurencyjności, rozumianej jako sprawność zyskiwania preferencji klientów, więcej w: J. Mazur, Zarządzanie marketingiem ustug, Difin, Warszawa 2001. 
klientów. Z uwagi na charakter wolnych zawodów oraz cechy usług profesjonalnych ${ }^{8}$ stwierdzić można, że wśród usługodawców w stosunku do konkurentów rynkowych dominują raczej zachowania kooperacyjne niż konfrontacyjne. Postawa ta przejawia się głównie w unikaniu otwartej walki konkurencyjnej oraz czasami w poszukiwaniu sojuszników rynkowych. Kolejną cechą usług profesjonalnych jest fakt, że co do zasady wynik świadczenia nie może być z góry zagwarantowany. Dlatego częściej konkuruje się w tych usługach jakością świadczonych usług oraz sposobem obsługi. Powyższe sprawia, że szczególnego znaczenia w usługach profesjonalnych nabiera marketing relacyjny. Działania nastawione na realizację jego założeń, w tym oferowanie przez pracowników wysokiej jakości obsługi klienta, stają się kwestią kluczowa. Lojalny klient korzysta $\mathrm{z}$ większej liczby usług, co w rezultacie prowadzi do wzrostu zysku. Z powyższych powodów efektywne konkurowanie na rynku usług prawnych nie może ograniczać się tylko do stosunkowo kosztownego oraz mało skutecznego zdobywania nowych klientów. Zatem zarówno oferta, jak i inne działania prowadzone przez kancelarie prawne powinny być nastawione na utrzymanie dotychczasowych klientów.

Mając na uwadze specyfikę konkurencyjności w usługach profesjonalnych, zasadne jest autorskie zdefiniowanie konkurencyjności kancelarii prawnych. W artykule przyjęto następująca definicję: konkurencyjność kancelarii prawnych oznacza ich zdolność do pozyskiwania i utrzymywania klientów wyższą niż zdolność osiagana przez konkurentów. W kolejnej części szczegółowo przedstawiona zostanie specyfika konkurencyjności kancelarii prawnych.

\section{KONKURENCYJNOŚĆ KANCELARII PRAWNYCH}

Czynniki determinujące konkurencyjność są dość silnie zróżnicowane branżowo, dlatego w praktycznych próbach jej pomiaru powinno się dążyć do sporządzenia listy zmiennych istotnych dla konkurowania w danej branży. W przypadku kancelarii prawnych ocena udziału w rynku jest dodatkowo utrudniona, ponieważ rynek usług prawnych ma charakter rozproszony ${ }^{9}$, a do tego nie ma dostępnych danych dotyczacych konkurencyjności publikowanych przez organy administracyjne lub samorządy zawodowe adwokatów lub radców prawnych. Ponadto ze względu na substytucyjność będąca wynikiem działalności doradców prawnych zachodzi problem z określeniem bezpośrednich konkurentów branych pod uwagę przy ocenie udziału w rynku. W takiej sytuacji najlepszym źródłem wiedzy o konkurentach są obsługiwani usługobiorcy. Klienci niezadowoleni z usług dotychczasowego prawnika chętnie opowiadaja o aspektach współpracy, które im nie odpowiadały, oraz wskazuja, co ich zdaniem należałoby zmienić. Dzięki temu prawnicy wiedza, co moga zrobić lepiej od konkurencji i gdzie moga okazać się skuteczniejsi. Prawnicy moga zdobywać wiedzę dotyczącą swoich konkurentów również dzięki analizie rankingów

\footnotetext{
${ }^{8}$ Chodzi zwłaszcza o niezależność oraz zasady etyki zawodowej.

${ }_{9}^{9}$ M. E. Porter, Strategie konkurencji. Metody analizy sektorów i konkurentów, PWE, Warszawa 1992 , s. 239-263.
} 
kancelarii prawnych. W Polsce za najbardziej prestiżowe uznawane sa rankingi prowadzone przez „Rzeczpospolita” oraz przez „Gazetę Prawną”. Najlepsi wyłaniani są według największej liczby prawników bądź rocznej wielkości obrotu lub zysku, bądź według największych transakcji obsłużonych przez daną kancelarię. Rankingi pomimo wielu zalet mają też wady. Główną niedoskonałością jest fakt, że opisują najczęściej największe i najbardziej znane kancelarie, które stanowią jednak znacząca mniejszość ogółu. Informacje o konkurencji prawnicy mogą czerpać również z Internetu oraz z branżowych publikacji. Wiedzę o konkurentach, ich sposobie świadczenia usług oraz polityce cenowej może dostarczyć również analiza otwartych przetargów na obsługę prawną ${ }^{10}$.

$\mathrm{W}$ usługach prawnych konkurowanie jest utrudnione również dlatego, że prawnicy albo wcale nie moga się reklamować, albo jest to bardzo utrudnione. Obowiązujący polskich adwokatów bezwzględny zakaz reklamy ma wieloletnią sięgająca okresu międzywojennego tradycję. Zarówno przed wojną jak i w latach późniejszych adwokatura sprzeciwiała się jakimkolwiek formom reklamowania swoich usług ${ }^{11}$. Natomiast radcowie prawni moga stosować marketing i reklamę, jeśli są one zgodne z prawem i godnością zawodu. Radcowie prawni moga obecnie informować klientów o efektach świadczonych usług, o ilości prowadzonych i wygrywanych spraw, o miejscach zajmowanych w rankingach. Sprawia to, że klientom łatwiej jest dokonać wyboru. Liberalizacja zasad etyki radców prawnych nie spowodowała jednak pełnej wolności i dowolności działań, nie doprowadziła do pojawienia się billboardów czy innych drapieżnych metod, np. napastliwość w szpitalach czy na lotniskach podczas katastrof ${ }^{12}$.

Konkurowanie o klientów może się odbywać w oparciu o wiele determinant rynkowych. Tradycyjnie wyróżnia się cenowe ${ }^{13}$ oraz pozacenowe czynniki konkurencyjności. Konkurencja pozacenowa polega na rywalizacji pomiędzy przedsiębiorstwami opartej na wykorzystywaniu innych niż cenowe charakterystyki, które wpływają na decyzje klientów o zawarciu transakcji. Do charakterystyk tych zaliczyć można przede wszystkim: jakość usług i sposób obsługi klienta, markę, formę płatności, warunki gwarancji, czas świadczenia usługi, niższe koszty eksploatacji, zakres oferowanych usług i wiele innych ${ }^{14}$. Do stosunkowo często uznawanych źródeł trwałej przewagi konkurencyjnej należy również właściwe kształtowanie relacji z klientami ${ }^{15}$. W usługach prawnych dodatkowo znaczenie mogą mieć: osiagnięty wynik w postaci wygranej spra-

${ }^{10}$ D. Hołubiec (red.), Zarządzanie kancelaria prawna. 100 najważniejszych pytań, jak robić to skutecznie, Wolters Kluwer Polska, Warszawa 2010, s. 203-204.

11 E. Krzemiński, Etyka adwokacka. Komentarz, Wolters Kluwer, Warszawa 2003, s. 110-117.

12 D. Hołubiec (red.), op. cit., s. 143-145.

${ }^{13}$ Rynki dóbr i usług, na których producenci konkurują tylko cenami, stanowią rzadkość, co spowodowane jest m.in. różnicą w jakości oferowanych usług. Jednocześnie w przypadku usług prawnych cena nie stanowi dobrej podstawy przewagi konkurencyjnej ze względu na niską wrażliwość cenową klientów, wynikającą z charakteru usług profesjonalnych.

${ }^{14}$ K. Bradło, Konkurencja cenowa i pozacenowa, http://mfiles.pl/pl/index.php/Konkurencja_ cenowa_i_pozacenowa [dostęp: 11.07.2014].

15 Wynika to z faktu powtarzalności kontaktów klientów z kancelaria, dlatego nie wystarczy ich pozyskać jednorazowo, zapewniając korzystną dla nich ofertę, ale konieczne jest jej zachowanie i utrzymanie jak najdłużej pozytywnych relacji z nimi. 
wy, podejmowanie wszelkich możliwych w danej sytuacji działań, przekonanie klienta o dobrze ulokowanych środkach i otrzymaniu wartościowego świadczenia, wiedza merytoryczna prawników, doświadczenie, specjalizacja lub materialne środki świadczenia usług ${ }^{16}$. W kolejnej części przedstawione zostaną wyniki badania empirycznego dotyczące oceny czynników konkurencyjności przez prawników.

\section{ZAŁOŻENIA METODYCZNE PRZEPROWADZONEGO BADANIA EMPIRYCZNEGO}

Część empiryczną artykułu rozpocznie opis założeń metodycznych przeprowadzonego badania oraz charakterystyka kancelarii prawnych objętych badaniem. Następnie przedstawione zostaną wyniki przeprowadzonego badania dotyczące czynników konkurencyjności kancelarii prawnych. W przeprowadzonym badaniu ilościowym analizie poddano kancelarie prawne, zarówno adwokackie, jak i radcowskie, zatrudniające co najmniej dwóch prawników ${ }^{17}$. Ze względu na czasochłonność i wysokie koszty zaplanowanych badań zakres przestrzenny ograniczono do obszaru Wielkopolski ${ }^{18}$. Uczestnikami badania byli właściciele/wspólnicy kancelarii prawnych. Celem badania było m.in. ustalenie oceny wybranych czynników konkurencyjności przez uczestników badania. Badanie zrealizowano z wykorzystaniem metody ankietowej. Wstępna wersja kwestionariusza ankiety została poddana weryfikacji przez badanie pilotażowe, podczas którego zebrano 40 wypełnionych kwestionariuszy. Właściwe badanie ilościowe przeprowadzono w miesiacach maj-czerwiec 2014 r. Kwestionariusze ankiety były dostarczane w wersji papierowej za pośrednictwem poczty, a ponadto wysyłano na adres e-mail kancelarii kwestionariusz do wydruku w formacie pdf oraz link do ankiety online. Kwestionariusz ankiety online został umieszczony na domenie Uniwersytetu Ekonomicznego w Poznaniu (badanie-kancelarii.ue.poznan.pl), co podniosło wiarygodność badania ${ }^{19}$. W wyniku analizy baz danych Okręgowej Rady Adwokackiej w Poznaniu oraz Okręgowej Izby Radców Prawnych w Poznaniu, a także „Rankingu kancelarii prawniczych 2014” opracowanego przez „Rzeczpospolitą” autor ustalił ogólną liczbę

\footnotetext{
${ }^{16}$ W części empirycznej artykułu wyróżniono i analizie poddano 38 czynników konkurencyjności kancelarii prawnych.

${ }^{17} \mathrm{Sa}$ to kancelarie małe, średnie oraz duże. Z uwagi na odmienną specyfikę zarządzania w części empirycznej pominięto kancelarie jednoosobowe.

${ }^{18}$ Używane w artykule pojęcie „z obszaru Wielkopolski” oznacza dokładnie kancelarie z obszaru działania Okręgowej Izby Radców Prawnych w Poznaniu oraz Izby Adwokackiej w Poznaniu.

${ }^{19}$ Kwestionariusz został stworzony przy wykorzystaniu oprogramowania Lime Survey będacego typem systemu Computer-Assisted Web Interview (CAWI). Oprogramowanie to umożliwiło zbieranie danych oraz ich analizę. Autor ograniczył dostęp do ankiety online, wysyłając zaproszenie do udziału w badaniu wraz z adresem internetowym, pod którym znajduje się kwestionariusz, tylko do wybranej grupy osób (przedstawicieli kancelarii prawnych). Ograniczenie to wykluczyło możliwość udzielania odpowiedzi przez respondentów spoza badanej populacji.
} 
kancelarii prawnych z obszaru Wielkopolski zatrudniajacych co najmniej 2 prawników na 236. Wśród nich 15 występowało zarówno w bazach danych korporacji adwokackiej, jak i radcowskiej, dlatego ostateczna liczba kancelarii stanowiących populacje generalną to 221 kancelarii prawnych. Wypełnione kwestionariusze otrzymano ze 115 kancelarii prawnych, co oznacza zwrotność na poziomie 52,03\%. Poniżej przedstawiona została struktura kancelarii, których przedstawiciele wzięli udział w badaniu i wypełnili kwestionariusz ankiety (tab. 2). Struktura badanych kancelarii ze względu na liczbę zatrudnionych prawników przedstawiała się następująco: $67,8 \%$ stanowiły kancelarie małe zatrudniające od 2 do 5 prawników, 28,7\% - kancelarie średnie zatrudniajace od 6 do 30 prawników, a tylko 3,5\% - kancelarie duże, zatrudniające ponad 30 prawników. W celu dalszej analizy postanowiono połaczyć grupę średnich i dużych kancelarii, które łącznie stanowiły $32,2 \%$ badanej populacji.

Struktura badanych kancelarii ze względu na rok ich powstania przedstawiała się następująco: 52,7\% badanych kancelarii powstało do $2005 \mathrm{r.}{ }^{20}$, a 47,3\% powstało w 2006 r. lub później. Wśród badanych kancelarii prawnych $46,1 \%$ specjalizowało się w obsłudze klientów indywidualnych, 36,5\% - w obsłudze klientów instytucjonalnych, a 17,4\% - w obsłudze obu grup klientów.

\section{Tabela 2}

Struktura kancelarii biorących udział w badaniu ze względu na wybrane cechy ${ }^{21}$

\begin{tabular}{|c|c|c|c|c|}
\hline Lp. & \multicolumn{2}{|c|}{ Cechy kancelarii biorących udział w badaniu } & Liczebność & Udzial \\
\hline \multirow{3}{*}{1.} & \multirow{3}{*}{ Rok powstania kancelarii ${ }^{21}$} & do $2005 \mathrm{r}$. & 49 & $42,6 \%$ \\
\hline & & od 2006 r. & 44 & $38,3 \%$ \\
\hline & & brak danych & 22 & $19,1 \%$ \\
\hline \multirow{3}{*}{2.} & \multirow{3}{*}{ Liczba zatrudnionych prawników } & $2-5$ & 78 & $67,8 \%$ \\
\hline & & $6-30$ & 33 & $28,7 \%$ \\
\hline & & powyżej 30 & 4 & $3,5 \%$ \\
\hline \multirow{3}{*}{3.} & \multirow{3}{*}{ Specjalizacja w obsłudze klientów } & indywidualnych & 53 & $46,1 \%$ \\
\hline & & instytucjonalnych & 42 & $36,5 \%$ \\
\hline & & z obu grup & 20 & $17,4 \%$ \\
\hline
\end{tabular}

Źródło: opracowanie własne na podstawie wyników przeprowadzonego badania.

${ }^{20}$ W latach 2005-2006 rozpoczął się proces szerszego otwarcia dostępu absolwentów studiów prawniczych do zawodów adwokata oraz radcy prawnego.

${ }^{21}$ Kategoria nie sumuje się do 115 , ponieważ nie wszyscy respondenci udzielili odpowiedzi na to pytanie. 
Analiza czynników konkurencyjności kancelarii prawnych

$\mathrm{Na}$ podstawie przeanalizowanej literatury oraz przeprowadzonego badania pilotażowego ${ }^{22}$ zidentyfikowano 38 następujących czynników konkurencyjności kancelarii prawnych: odpowiadanie na potrzeby i oczekiwania klientów; rzetelność; dotrzymywanie złożonych w kontaktach z klientami zobowiązań; terminowość realizacji usług i informowanie klienta na bieżąco o wszelkich zmianach; udzielanie klientom wyczerpujacych i zrozumiałych dla nich informacji; troska personelu o sprawy nabywcy usługi; umiejętność wzbudzania zaufania; umiejętność udzielania klientowi praktycznych porad; dostosowanie czasu obsługi do wymagań klienta (np. godziny otwarcia); umożliwienie klientowi preferencyjnego sposobu opłacania należności; sprawna i szybka obsługa (np. wysyłanie pism przed terminem); życzliwa i miła obsługa; widoczne zaangażowanie personelu - gotowość do udzielania pomocy; wygląd zewnętrzny i wystrój kancelarii; sposób ubioru prawnika i estetyka ubioru personelu; doświadczenie (okres funkcjonowania kancelarii); tradycja i historia kancelarii; wizerunek kancelarii/ reputacja prawników; specjalizacja w niszowej dziedzinie; niskie ceny usług; dogodna lokalizacja kancelarii; wysoki poziom kompetencji prawnych i wiedzy merytorycznej; zatrudnianie w kancelarii uznanego specjalisty (osób z tytułami naukowymi); nawiązanie współpracy z renomowanym partnerem zagranicznym; struktura organizacyjna kancelarii; funkcjonowanie administracji kancelarii (sekretariatu, archiwum); niskie koszty prowadzenia działalności oraz ich redukcja; przestrzeganie zasad etyki zawodowej; działania marketingowe mające na celu promocję kancelarii; rodzaj świadczonych usług (do jakich klientów jest kierowana oferta); wprowadzanie nowych produktów lub usług komplementarnych; wyróżniająca się strona internetowa; pozycjonowanie strony internetowej w wyszukiwarkach internetowych; promocja w Internecie np.: media społecznościowe (Facebook, Twitter, YouTube, LinkedIn, GoldenLine); prowadzenie strony internetowej/bloga; technologia - informatyzacja lub jakakolwiek inna przewaga technologiczna oraz korzystanie z informatycznych programów do zarządzania kancelarią. Poniżej, w tabeli 3, przedstawiono średnie oceny czynników konkurencyjności kancelarii prawnych.

Za najbardziej istotne dla oceny konkurencyjności kancelarii prawnych uczestnicy badania uznali czynniki o charakterze jakościowym, które oparte zostały przede wszystkim na służącej badaniu jakości usług metodzie SERVQUAL ${ }^{23}$, przy uwzględnieniu specyfiki zarządzania kancelarią prawną.

${ }^{22}$ Respondenci zostali poproszeni o przeanalizowanie wszystkich czynników konkurencyjności występujących w kwestionariuszu badania pilotażowego oraz o sformułowanie uwag, spostrzeżeń i własnych sugestii, a przede wszystkim o próbę rozszerzenia listy. Finalnym efektem przeprowadzonych badań pilotażowych było skonstruowanie nowej, rozwiniętej listy czynników konkurencyjności kancelarii prawnych.

${ }^{23}$ Obszerny opis istoty metody SERVQUAL można znaleźć m.in w: A. Parasuraman, V. A. Zeithaml, L. L. Berry, SERVQUAL: a multiple-item scale for measuring consumer perceptions of service quality, „Journal of Retailing” 64(1), 1988, s. 12-39. 
Tabela 3

Ocena czynników konkurencyjności kancelarii prawnych

\begin{tabular}{|c|c|}
\hline Czynnik konkurencyjności & $\begin{array}{l}\text { Ocena czynnika } \\
\text { w skali od } 1 \text { do } 5\end{array}$ \\
\hline Rzetelność & 4,54 \\
\hline Dotrzymywanie złożonych klientom zobowiązań & 4,51 \\
\hline Umiejętność udzielania klientom praktycznych porad & 4,49 \\
\hline Udzielanie klientom wyczerpujących informacji & 4,47 \\
\hline Wysoki poziom wiedzy i kompetencji prawnych & 4,41 \\
\hline Terminowość realizacji usług & 4,39 \\
\hline Umiejętność wzbudzania zaufania & 4,34 \\
\hline Widoczne zaangażowanie personelu & 4,28 \\
\hline Reputacja prawników/ wizerunek kancelarii & 4,27 \\
\hline Życzliwa i miła obsługa & 4,27 \\
\hline Odpowiadanie na potrzeby i oczekiwania klientów & 4,25 \\
\hline Doświadczenie - okres funkcjonowania kancelarii & 4,03 \\
\hline Troska personelu o sprawy klienta & 4,01 \\
\hline Specjalizacja w niszowej dziedzinie & 3,99 \\
\hline Sprawna i szybka obsługa & 3,97 \\
\hline Sposób ubioru prawnika i estetyka ubioru personelu & 3,80 \\
\hline Pozycjonowanie strony WWW w wyszukiwarkach internetowych & 3,70 \\
\hline Przestrzeganie zasad etyki zawodowej & 3,69 \\
\hline Dostosowanie czasu obsługi do wymagań klienta & 3,69 \\
\hline Zatrudnianie w kancelarii uznanego specjalisty & 3,67 \\
\hline Rodzaj świadczonych usług & 3,52 \\
\hline Tradycja i historia kancelarii & 3,50 \\
\hline Wyróżniająca się strona internetowa & 3,48 \\
\hline Umożliwienie preferencyjnego sposobu opłacania należności & 3,42 \\
\hline Niskie ceny usług & 3,37 \\
\hline Dogodna lokalizacja kancelarii & 3,19 \\
\hline Prowadzenie strony WWW/ bloga prawniczego & 3,18 \\
\hline Wygląd zewnętrzny i wystrój kancelarii & 3,15 \\
\hline Wprowadzanie nowych produktów lub usług komplementarnych & 3,10 \\
\hline Informatyzacja/ przewaga technologiczna & 3,10 \\
\hline Działania marketingowe/ promocja kancelarii & 3,03 \\
\hline Promocja w Internecie, np. media społecznościowe & 3,00 \\
\hline Funkcjonowanie administracji kancelarii & 2,97 \\
\hline Korzystanie z informatycznych programów do zarządzania kancelarią & 2,93 \\
\hline Współpraca z renomowanym partnerem zagranicznym & 2,90 \\
\hline Redukcja kosztów prowadzenia działalności & 2,90 \\
\hline Struktura organizacyjna kancelarii & 2,67 \\
\hline
\end{tabular}

Źródło: opracowanie własne na podstawie wyników przeprowadzonego badania. 
Poszczególne cechy jakości usług prawnych zostały zatem przyporządkowane do pięciu podstawowych wymiarów, a mianowicie: solidności, pewności, zdolności reagowania, empatii oraz materialności. Co do zasady czynniki o charakterze jakościowym zostały ocenione przez uczestników badania znacznie wyżej niż inne czynniki. Potwierdzeniem większego znaczenia nadanego tym czynnikom przez uczestników badania jest przedstawienie zbiorcze dziesięciu najważniejszych czynników konkurencyjności kancelarii prawnych. Aż osiem z nich miało charakter jakościowy. Najwyżej ocenianymi przez uczestników badania czynnikami konkurencyjności o charakterze jakościowym były: rzetelność (4,54), dotrzymywanie złożonych klientom zobowiązań $(4,51)$ oraz umiejętność udzielania praktycznych porad $(4,49)$. Ogólnie stwierdzić więc można, że dla respondentów najważniejsze były czynniki należące do szeroko pojmowanej solidności świadczenia usług, czyli zdolności usługodawcy do zrealizowania obiecanej usługi we właściwy sposób i na obiecanym poziomie - dokładnie, solidnie, niezawodnie, rzetelnie i na czas. Zauważyć można też ogólną tendencję, że wyżej ocenione zostały czynniki dotyczące samego procesu świadczenia usług niż materialnych środków ich świadczenia. Dzięki temu ukazana została naczelna rola współpracy usługodawców z usługobiorcami, prowadząca do doskonalenia obsługi nabywców.

Czynniki o charakterze innym niż jakościowy nie zostały ocenione wysoko przez uczestników badania i tylko w trzech przypadkach ich średnia ocena przekroczyła 4,0. Były to: wysoki poziom wiedzy merytorycznej i kompetencji prawnych $(4,41)$, reputacja prawników/ wizerunek kancelarii $(4,27)$ oraz okres funkcjonowania kancelarii $(4,03)$. Co ciekawe, stosunkowo nisko ocenione zostały szeroko opisywane przez praktyków biznesu czynniki dotyczące działalności kancelarii w Internecie, takie jak: pozycjonowanie strony internetowej w wyszukiwarkach internetowych $(3,70)$, wyróżniająca się strona internetowa $(3,48)$, prowadzenie strony internetowej/ bloga $(3,18)$, przewaga technologiczna $(3,10)$, promocja w Internecie $(3,00)$ lub korzystanie z wiodacych informatycznych programów do zarządzania kancelarią $(2,93)$. Uczestnicy badania zaskakująco nisko ocenili też podstawowe, jak wydawałoby się, czynniki konkurencyjności kancelarii prawnych, takie jak: niskie ceny usług $(3,37)$ czy dogodna lokalizacja kancelarii $(3,19)$.

Oprócz przedstawienia najważniejszych czynników konkurencyjności dla wszystkich kancelarii prawnych, dokonano również wyróżnienia dziesięciu najważniejszych czynników konkurencyjności ze względu na następujące kryteria: wielkość kancelarii, rok powstania kancelarii, specjalizacja kancelarii prawnych w obsłudze określonych grup klientów. Poniżej przedstawiono szczegółowe wyniki analizy. W tabeli 4 zamieszczono dziesięć najważniejszych czynników konkurencyjności małych kancelarii prawnych (zatrudniających od 2 do 5 prawników) oraz średnich i dużych kancelarii prawnych (zatrudniających więcej niż 6 prawników).

Można zauważyć pewne różnice w ocenie czynników konkurencyjności przez przedstawicieli wymienionych grup, jednakże nie są to różnice znaczne, 
ponieważ 8 czynników zostało uznanych za najważniejsze w obu grupach. Najwyżej ocenianym czynnikiem dla małych kancelarii była rzetelność $(4,54)$, a dla średnich i dużych - dotrzymywanie złożonych klientom zobowiązań $(4,57)$. Warto zwrócić uwagę na fakt, że generalnie czynnikom o charakterze jakościowym przypisywano większy wpływ na konkurencyjność w średnich i dużych kancelariach prawnych.

\section{Tabela 4}

Dziesięć najważniejszych czynników konkurencyjności kancelarii prawnych zatrudniających od 2 do 5 i powyżej 6 prawników

\begin{tabular}{|c|c|c|c|}
\hline $\begin{array}{l}\text { Czynnik konkurencyjności } \\
\text { - kancelarie zatrudniające } \\
\text { od } 2 \text { do } 5 \text { prawników }\end{array}$ & $\begin{array}{l}\text { Ocena } \\
\text { czynnika } \\
\text { w skali } \\
\text { od } 1 \text { do } 5\end{array}$ & $\begin{array}{l}\text { Czynnik konkurencyjności } \\
\text { - kancelarie zatrudniające } \\
\text { powyżej } 6 \text { prawników }\end{array}$ & $\begin{array}{l}\text { Ocena } \\
\text { czynnika } \\
\text { w skali } \\
\text { od } 1 \text { do } 5\end{array}$ \\
\hline Rzetelność & 4,54 & $\begin{array}{l}\text { Dotrzymywanie złożonych } \\
\text { klientom zobowiązań }\end{array}$ & 4,57 \\
\hline $\begin{array}{l}\text { Dotrzymywanie złożonych } \\
\text { klientom zobowiązań }\end{array}$ & 4,49 & $\begin{array}{l}\text { Udzielanie klientom } \\
\text { wyczerpujących informacji }\end{array}$ & 4,54 \\
\hline $\begin{array}{l}\text { Umiejętność udzielania } \\
\text { klientom praktycznych porad }\end{array}$ & 4,46 & Terminowość realizacji usług & 4,54 \\
\hline $\begin{array}{l}\text { Udzielanie klientom } \\
\text { wyczerpujących informacji }\end{array}$ & 4,44 & Rzetelność & 4,54 \\
\hline $\begin{array}{l}\text { Umiejętność wzbudzania } \\
\text { zaufania }\end{array}$ & 4,38 & $\begin{array}{l}\text { Umiejętność udzielania } \\
\text { klientom praktycznych porad }\end{array}$ & 4,54 \\
\hline $\begin{array}{l}\text { Wysoki poziom wiedzy } \\
\text { i kompetencji prawnych }\end{array}$ & 4,37 & $\begin{array}{l}\text { Wysoki poziom wiedzy } \\
\text { i kompetencji prawnych }\end{array}$ & 4,49 \\
\hline Terminowość realizacji usług & 4,32 & $\begin{array}{l}\text { Widoczne zaangażowanie } \\
\text { personelu }\end{array}$ & 4,43 \\
\hline $\begin{array}{l}\text { Odpowiadanie na potrzeby } \\
\text { i oczekiwania klientów }\end{array}$ & 4,29 & $\begin{array}{l}\text { Reputacja prawników/ } \\
\text { wizerunek kancelarii }\end{array}$ & 4,32 \\
\hline Życzliwa i miła obsługa & 4,27 & Życzliwa i miła obsługa & 4,27 \\
\hline $\begin{array}{l}\text { Reputacja prawników/ } \\
\text { wizerunek kancelarii }\end{array}$ & 4,24 & $\begin{array}{l}\text { Troska personelu o sprawy } \\
\text { nabywcy }\end{array}$ & 4,27 \\
\hline
\end{tabular}

Źródło: opracowanie własne na podstawie wyników przeprowadzonego badania.

W tabeli 5 przedstawiono dziesięć najważniejszych czynników konkurencyjności dla kancelarii prawnych powstałych do 2005 r. oraz powstałych w 2006 i później. Nie wystapiły znaczne różnice w ocenie, a dziewięć czynników wystapiło w różnej kolejności w obu grupach. Ogólnie można stwierdzić, że czynniki o charakterze jakościowym odgrywają większą rolę w kancelariach założonych w 2005 r. i wcześniej. 


\section{Tabela 5}

Dziesięć najważniejszych czynników konkurencyjności kancelarii prawnych powstałych do 2005 r. i kancelarii działających od 2006 r.

\begin{tabular}{|l|c|l|c|}
\hline $\begin{array}{c}\text { Czynnik konkurencyjności } \\
\text { - kancelarie powstałe do } \\
\mathbf{2 0 0 5} \text { r. }\end{array}$ & $\begin{array}{c}\text { Ocena } \\
\text { czynnika } \\
\text { w skali } \\
\text { od 1 do 5 }\end{array}$ & $\begin{array}{c}\text { Czynnik konkurencyjności } \\
\text { - kancelarie powstałe } \\
\text { w 2006 r. i później }\end{array}$ & $\begin{array}{c}\text { Ocena } \\
\text { czynnika } \\
\text { w skali } \\
\text { od 1 do 5 }\end{array}$ \\
\hline Rzetelność & 4,65 & Rzetelność & 4,45 \\
\hline $\begin{array}{l}\text { Dotrzymywanie złożonych } \\
\text { klientom zobowiązań }\end{array}$ & 4,65 & $\begin{array}{l}\text { Umiejętność udzielania } \\
\text { klientom praktycznych porad }\end{array}$ & 4,45 \\
\hline $\begin{array}{l}\text { Wysoki poziom wiedzy } \\
\text { i kompetencji prawnych }\end{array}$ & 4,63 & $\begin{array}{l}\text { Udzielanie klientom } \\
\text { wyczerpujących informacji }\end{array}$ & 4,39 \\
\hline $\begin{array}{l}\text { Udzielanie klientom } \\
\text { wyczerpujących informacji }\end{array}$ & 4,55 & $\begin{array}{l}\text { Dotrzymywanie złożonych } \\
\text { klientom zobowiązań }\end{array}$ & 4,36 \\
\hline Terminowość realizacji usług & 4,53 & $\begin{array}{l}\text { Umiejętność wzbudzania } \\
\text { zaufania }\end{array}$ & 4,34 \\
\hline $\begin{array}{l}\text { Umiejętność udzielania } \\
\text { klientom praktycznych porad }\end{array}$ & 4,53 & $\begin{array}{l}\text { Odpowiadanie na potrzeby } \\
\text { i oczekiwania klientów }\end{array}$ & 4,27 \\
\hline $\begin{array}{l}\text { Reputacja prawników/ } \\
\text { wizerunek kancelarii }\end{array}$ & 4,37 & $\begin{array}{l}\text { Wysoki poziom wiedzy } \\
\text { i kompetencji prawnych }\end{array}$ & 4,25 \\
\hline $\begin{array}{l}\text { Widoczne zaangażowanie } \\
\text { personelu }\end{array}$ & 4,37 & Terminowość realizacji usług & 4,23 \\
\hline $\begin{array}{l}\text { Umiejętność wzbudzania za- } \\
\text { ufania }\end{array}$ & 4,35 & $\begin{array}{l}\text { Widoczne zaangażowanie } \\
\text { personelu }\end{array}$ & 4,23 \\
\hline $\begin{array}{l}\text { Odpowiadanie na potrzeby } \\
\text { i oczekiwania klientów }\end{array}$ & Życzliwa i miła obsługa \\
\hline
\end{tabular}

Źródło: opracowanie własne na podstawie wyników przeprowadzonego badania.

W tabeli 6 przedstawiono dziesięć najważniejszych czynników konkurencyjności odpowiednio dla kancelarii prawnych specjalizujących się w obsłudze klientów indywidualnych oraz klientów instytucjonalnych. Nie wystapiły znaczne różnice w ocenach w poszczególnych grupach, a dziewięć czynników wystapiło w różnej kolejności w obu grupach. Ponadto trzy najważniejsze czynniki (rzetelność, dotrzymywanie złożonych klientom zobowiązań oraz umiejętność udzielania klientom praktycznych porad) zostały ocenione identycznie w obu grupach w takiej samej kolejności. Ogólnie można stwierdzić, że czynniki o charakterze jakościowym odgrywają większą rolę w kancelariach specjalizujących się w obsłudze klientów instytucjonalnych. 


\section{Tabela 6}

Dziesięć najważniejszych czynników konkurencyjności kancelarii prawnych specjalizujących się w obsłudze klientów indywidualnych i klientów instytucjonalnych

\begin{tabular}{|c|c|c|c|}
\hline $\begin{array}{l}\text { Czynnik konkurencyjności - } \\
\text { kancelarie specjalizujące się } \\
\text { w obsłudze klientów } \\
\text { indywidualnych }\end{array}$ & $\begin{array}{l}\text { Ocena } \\
\text { czynnika } \\
\text { w skali } \\
\text { od } 1 \text { do } 5\end{array}$ & $\begin{array}{l}\text { Czynnik konkurencyjności - } \\
\text { kancelarie specjalizujące się } \\
\text { w obsłudze klientów } \\
\text { instytucjonalnych }\end{array}$ & $\begin{array}{l}\text { Ocena } \\
\text { czynnika } \\
\text { w skali } \\
\text { od } 1 \text { do } 5\end{array}$ \\
\hline Rzetelność & 4,53 & Rzetelność & 4,55 \\
\hline $\begin{array}{l}\text { Dotrzymywanie złożonych } \\
\text { klientom zobowiązań }\end{array}$ & 4,49 & $\begin{array}{l}\text { Dotrzymywanie złożonych } \\
\text { klientom zobowiązań }\end{array}$ & 4,52 \\
\hline $\begin{array}{l}\text { Umiejętność udzielania } \\
\text { klientom praktycznych porad }\end{array}$ & 4,45 & $\begin{array}{l}\text { Umiejętność udzielania } \\
\text { klientom praktycznych porad }\end{array}$ & 4,52 \\
\hline $\begin{array}{l}\text { Udzielanie klientom } \\
\text { wyczerpujących informacji }\end{array}$ & 4,43 & $\begin{array}{l}\text { Udzielanie klientom } \\
\text { wyczerpujących informacji }\end{array}$ & 4,48 \\
\hline $\begin{array}{l}\text { Umiejętność wzbudzania } \\
\text { zaufania }\end{array}$ & 4,40 & $\begin{array}{l}\text { Wysoki poziom wiedzy } \\
\text { i kompetencji prawnych }\end{array}$ & 4,48 \\
\hline $\begin{array}{l}\text { Wysoki poziom wiedzy } \\
\text { i kompetencji prawnych }\end{array}$ & 4,36 & Terminowość realizacji usług & 4,40 \\
\hline Terminowość realizacji usług & 4,34 & $\begin{array}{l}\text { Umiejętność wzbudzania } \\
\text { zaufania }\end{array}$ & 4,38 \\
\hline $\begin{array}{l}\text { Reputacja prawników/ wizeru- } \\
\text { nek kancelarii }\end{array}$ & 4,28 & $\begin{array}{l}\text { Widoczne zaangażowanie } \\
\text { personelu }\end{array}$ & 4,38 \\
\hline Życzliwa i miła obsługa & 4,23 & $\begin{array}{l}\text { Odpowiadania na potrzeby } \\
\text { i oczekiwania klientów }\end{array}$ & 4,38 \\
\hline $\begin{array}{l}\text { Widoczne zaangażowanie per- } \\
\text { sonelu }\end{array}$ & 4,21 & Życzliwa i miła obsługa & 4,36 \\
\hline
\end{tabular}

Źródło: opracowanie własne na podstawie wyników przeprowadzonego badania.

Wyniki przeprowadzonego badania pozwalaja dostrzec, że prawnicy postrzegają konkurencyjność nie tylko jako formę rywalizacji ${ }^{24}$, lecz także jako sposób działania prowadzącego do budowania długotrwałych relacji z klientami przez doskonalenie jakości świadczonych usług. Głównym założeniem nurtu współpracy, który wywodzi się z koncepcji marketingu relacyjnego, jest po-

${ }_{24}$ Tradycyjny model konkurencji rynkowej oparty jest na następujących założeniach: rozstanie klienta z firmą sprawia, że „krąży” on między różnymi wytwórcami produktów w nadziei na znalezienie lepszych dla siebie wykonawców i produktów o wyższej jakości. Rozstanie z klientem rodzi presję na wykonawcę, by usprawnił swoje funkcjonowanie i zwiększył starania o rezultaty, co wpływa na podnoszenie efektywności ekonomicznej przedsiębiorstw. Więcej w: K. Rogoziński, Zarzadzanie wartościq z klientem, Oficyna Wolters Kluwer Business, Warszawa 2012, s. 294. Słowem, bardziej mobilny popyt i rotowanie klientów sprzyjają lepszemu i bardziej efektywnemu funkcjonowaniu poszczególnych przedsiębiorstw. W takim ujęciu zakłada się, że organizacje konkurują o dominującą pozycję w dostępie do ograniczonych zasobów, a podstawową miarą sukcesu (rozumianego jako osiagnięta przewaga konkurencyjna) jest udział w rynku. Ponadto zakłada się, że firmy mogą mieć skłonność do wzajemnego zwalczania się i mieć zasoby potrzebne do długotrwałego i energicznego przeciwdziałania. Zob. M. E. Porter, op. cit., s. 22. 
łożenie nacisku przez organizacje usługowe nie na pokonanie konkurentów ${ }^{25}$, ale na budowanie trwałych relacji z klientami. W takim ujęciu zakłada się, że organizacje świadczące usługi profesjonalne nie eliminują się nawzajem, ale pozwalają przejść konkurentom mimochodem, rywalizując dzięki dążeniu do przekształcania jakości w kategorię naprowadzająca na wartość. Podstawowa miarą sukcesu jest dla nich posiadanie korzyśsi wynikających z długookresowej współpracy.

Ponadto w usługach profesjonalnych rywalizować można jeszcze w inny sposób: dążeniem do mistrzostwa, perfekcyjnością wykonania, samorozwojem potwierdzonym uzyskiwaniem stopni naukowych ${ }^{26}$. Przy zachowaniu wyżej wymienionych warunków można stwierdzić, że profesjonaliści (prawnicy) oraz kancelarie prawne bardziej przyciagaja, niż eliminują klientów. Potwierdzeniem takiego podejścia do konkurencyjności są reguły zapisane w branżowych kodeksach etyki. Na przykład zgodnie z § 23b pkt 2c Kodeksu etyki adwokac$\mathrm{kiej}^{27}$ adwokaci nie mogą ujawniać informacji, które zawieraja bezpośrednie porównania w zakresie jakości z innymi możliwymi do identyfikacji adwokatami i członkami innych korporacji prawniczych lub dokonywać ich krytyki. Zgodnie z $§ 24$ Kodeksu adwokaci powinni służyć sobie radą i udzielać wzajemnej pomocy w pracy zawodowej, jeżeli nie koliduje to z interesem klienta, a $\S 31$ pkt 1 stanowi, że adwokat powinien przestrzegać w stosunku do kolegów zasad uprzejmości, lojalności i koleżeństwa. Z kolei zgodnie z art. 32 Kodeksu etyki radcy prawnego $0^{28}$ radcy obowiązani sa przestrzegać lojalności i koleżeństwa wobec wszystkich członków samorządu, a zgodnie z art. 33 powinni udzielać sobie pomocy i służyć rada w sprawach związanych z wykonywaniem zawodu, o ile to nie szkodzi interesom podmiotów, na rzecz których świadcza pomoc prawna.

W artykule przyjęto również, że można oceniać konkurencyjność kancelarii prawnych, kierując się kryterium ich pozycji konkurencyjnej. Uczestnicy badania oceniali swoją pozycję konkurencyjna w skali: bardzo dobra, dobra, średnia, słaba oraz bardzo słaba. Wśród ogółu badanych kancelarii najwięcej 47,0\% określiło swoja pozycję jako dobra. Mniej, czyli 26,1\%, zadeklarowało, że ich pozycja konkurencyjna jest średnia, natomiast $15,7 \%$ - że bardzo dobra. Znacznie mniej uczestników wskazywało na pozycję słabą i bardzo słabą ( $6,1 \%$ i 1,7\%). Opinie uczestników badania o pozycji konkurencyjnej swoich kancelarii należy zatem uznać za pozytywne.

Następnie dokonano analizy postrzeganej przez uczestników badania pozycji konkurencyjnej kancelarii ze względu na wyróżnione kryteria, co pozwoliło odkryć, że ważnymi determinantami konkurencyjności sa: rok powstania kancelarii, jej wielkość oraz specjalizacja w obsłudze określonej grupy klien-

${ }_{25}$ Termin „konkurencja” pochodzi od łacińskiego concurrere, które znaczy „biec razem”.

${ }^{26}$ K. Rogoziński, Zarzadzanie wartościq..., s. 293-299.

${ }^{27}$ Zob. Zbiór zasad etyki adwokackiej i godności zawodu (Kodeks etyki adwokackiej) uchwalony przez Naczelną Radę Adwokacką 10 października 1998 r. (uchwała nr 2/XVIII/98) ze zmianami wprowadzonymi uchwała Naczelnej Rady Adwokackiej nr 32/2005 z 19 listopada 2005 r. oraz uchwałami Naczelnej Rady Adwokackiej nr 33/2011 - 54/2011 z 19 listopada 2011 r.

${ }^{28}$ Zob. Kodeks etyki radcy prawnego, Załącznik do Uchwały Nr 5 VIII Krajowego Zjazdu Radców Prawnych z 10 listopada 2007 r. 
tów. Co ciekawe, poszczególne grupy kancelarii na ogół w podobny sposób postrzegały znaczenie czynników konkurencyjności, natomiast wystapiły duże różnice w ocenie własnej pozycji konkurencyjnej. Co do zasady swoją pozycję konkurencyjną najlepiej postrzegały kancelarie założone do 2005 r., średniej oraz dużej wielkości, specjalizujące się w obsłudze klientów instytucjonalnych oraz posiadajace duży udział stałych i lojalnych klientów.

\section{PODSUMOWANIE}

Wobec zachodzacych na polskim rynku usług prawnych dynamicznych zmian kancelarie prawne poszukują sposobów służących zdobywaniu i utrzymywaniu przewagi konkurencyjnej. Konkurencyjność kancelarii prawnych oznacza ich zdolność do pozyskiwania i utrzymywania klientów wyższą niż zdolność osiagana przez konkurentów. W artykule wyróżniono 38 czynników konkurencyjności kancelarii prawnych o charakterze jakościowym oraz niejakościowym i następnie dokonano ich porównania. Pod uwagę wzięto wyłącznie uwarunkowania oddziałujące na konkurencyjność w sposób pozytywny.

Oprócz przedstawienia najważniejszych czynników konkurencyjności zbiorczo dla wszystkich badanych kancelarii prawnych dokonano również wyróżnienia 10 najważniejszych czynników konkurencyjności ze względu na następujące kryteria: wielkość kancelarii, rok powstania kancelarii oraz specjalizacja kancelarii prawnych w obsłudze określonych grup klientów. Uzyskane wyniki pozwoliły zwrócić uwagę na związek pomiędzy jakością usług a konkurencyjnością kancelarii prawnych. Konkurowanie przez jakość to umiejętność takiego wykorzystania zasobów, które umożliwia uzyskanie przewagi nad konkurentami w postaci wyższej jakości, a także udokumentowanie tej przewagi na rynku w formie wyróżniającej pozycji konkurencyjnej. Kluczową perspektywą oceny pozycji konkurencyjnej organizacji usługowej jest perspektywa usługobiorcy. Z uwagi na specyfikę usług prawnych, w których nie można zagwarantować klientom osiagnięcia oczekiwanego rezultatu, usługodawcy konkuruja przede wszystkim przez zwracanie uwagi na jakość świadczonych usług oraz doskonalenie sposobu obsługi nabywców. Dzięki temu możliwe jest budowanie trwałych relacji z klientami zamiast wykorzystywania tychże klientów do prowadzenia walki z konkurentami.

Chociaż przedstawione w artykule ustalenia dostarczają nowej wiedzy dotyczącej konkurencyjności kancelarii prawnych - zdaniem autora - zasadne byłoby przeprowadzenie podobnego badania wśród kancelarii prawnych z obszaru całej Polski. Bardzo interesująca mogłaby się okazać również analiza porównawcza uzyskanych wyników z danymi uzyskanymi wśród zagranicznych kancelarii prawnych. Zagadnienia te autor chciałby podejmować w przyszłości w ramach dalszych prac badawczych.

dr Marek Gnusowski

Uniwersytet Ekonomiczny w Poznaniu

marek.gnusowski@ue.poznan.pl 


\section{METHODS OF COMPETING OF LAW FIRMS FROM THE WIELKOPOLSKA REGION}

\section{Summary}

The Polish legal services market is developing fast and the number of law firms is growing rapidly. They strive to build competitive advantage over other law firms and find more loyal customers. The aim of the study is to explain the concept of competitiveness of Polish law firms. A list of factors which contribute to their prosperity was formulated. The article contains the results of an empirical (quantitative) research into the relations between service quality and competitiveness of law firms in Wielkopolska (one of the biggest Polish regions) conducted by the author in 2014. 